figure: Aberdeen, with $\mathfrak{4 0 4 , 4 5 0}$ from public and 134,337 from other sources; Edinburgh, with $£ 738,037$ and $£ 345,198$; and Glasgow, with $£ 835,650$ and $£ 361,388$, respectively. The University of Wales, including the Welsh National School of Medicine, received $£ 847,960$ from public funds and $£ 327,164$ from other sources.

Of the total expenditure of $£ 24,269,862$, an increase of $£ 2,501,952$ on the previous year, administration accounted for $8 \cdot 7$ per cent, departmental maintenance $69 \cdot 7$, maintenance of premises $11 \cdot 1$, and miscellaneous expenditure $9 \cdot 4$ per cent. Capital expenditure met from reserves amounted to $£ 254,274$ and allocation to reserves, $£ 236,707$; for 1949-50, these figures were $£ 472,327$ and $£ 270,993$, respectively. Departmental maintenance included salaries of teaching and research staffs and payments for superannuation, the running costs of laboratories, lecture rooms, libraries and museums, and the supply of materials, apparatus, books, specimens, etc. Salaries and superannuation amounted to $£ 11,895,971$, an increase of $£ 1,349,625$ on the previous year; this represents $49 \cdot 1$ per cent of the total expenditure, compared with 48.4 per cent in 1949-50 and an 8.5 per cent increase in full-time staff.

Library expenditure, excluding general maintenance of library buildings, rates, heat, light, repairs, etc., amounted to $£ 891,385$ compared with $£ 788,402$ in $1949-50$, the percentage of total university expenditure remaining 3.7 per cent. Of this total, $£ 473,087$ was for salaries and wages, $£ 197,062$ on account of books and $£ 103,305$ on periodicals. The University of Oxford spent $£ 32,095$ on books, and Cambridge $£ 10,102$, while a total of $£ 51,025$

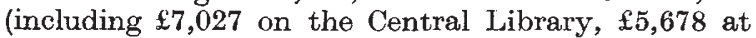
the London School of Economics and $£ 5,006$ at University College) was expended for this purpose in the colleges and schools of the University of London. Nine other universities, Birmingham (£5,102), Bristol $(£ 5,467)$, Leeds $(£ 6,638)$, Liverpool $(£ 8,111)$, Manchester (£9,092), Aberdeen (£6,995), Edinburgh $(£ 9,648)$, Glasgow $(£ 8,933)$ and St. Andrews $(£ 5,307)$, spent $£ 5,000$ or more on books, but only London (£30,496), Cambridge $(£ 7,542)$, Glasgow $(£ 7,263)$, Manchester $(£ 5,228)$ and Oxford $(£ 5,175)$ spent a like sum on periodicals.

While these returns show that university expansion in Britain has now been halted and afford signs, as in the increasing ratio of staff to students and the slight decrease in the proportion of art students, that the universities are already adjusting themselves to current requirements and seeking to maintain or raise standards, they also contain evidence of the vulnerability of such standards to extraneous pressure with the growing dependence of the universities upon State assistance. That in itself supports the contention of the Select Committee on Estimates in a recent report regarding the desirability of giving the fullest possible information to Parliament concerning the expenditure of the grant-in-aid of universities and colleges. A Treasury Memorandum included in the Eleventh Report from the Select Committee on Estimates for the Session 1951-52 (No. 289. London : H.M.S.O. $9 d$. net) accepts the recommendation of the Estimates Committee that a note should be inserted in the estimates reconciling the amount of the quinquennial grant proposed for the academic year with the total figure of recurrent grant shown in the estimates for the financial year, but the Treasury does not consider that the estimates are the most convenient vehicle for giving information to Parliament on changes in recurrent grants. The Treasury proposes to consider the best way of making any specific changes known to Parliament, but rejects the Estimates Committee's further recommendation that the Comptroller and Auditor-General should have the right to inspect the books and accounts of universities in respect of non-recurrent grants for capital development. The Treasury considers that the existing audit of university accounts already ensures that the grant is used for the purpose for which it is intended. The detailed scrutiny of expenditure on the design and equipment of buildings inevitably raises questions of academic policy, and in the Treasury view goes far beyond the broad lines on which control should be exercised if academic freedom is to be unimpaired. The Treasury believes that such scrutiny is best left to the University Grants Committee, and it is satisfied that this Committee, with the help of its own works and buildings sub-committee and of the Ministry of Works, scrutinizes all plans for which aid is sought and requires the universities to accept the lowest tender for their work unless good reason can be shown to the contrary.

The Treasury's attitude on this point is evidence of how firmly entrenched in Great Britain is the desire to safeguard academic freedom; but the universities are now too vulnerable to external conditions for the position to be regarded with complacency. The Treasury memorandum indicates that in accordance with a further recommendation of the Estimates Committee the terms of reference of the University Grants Committee will be revised to remove the obligation to collect, examine and disseminate information on university education abroad. Approval is also expressed of the recommendation regarding continuity in the senior full-time posts of the University Grants Committee.

\section{ELECTRICAL ENGINEERING IN BRITAIN}

$T$

HE inaugural address of Colonel H. B. Leeson, on taking office as president of the Institution of Electrical Engineers, was delivered on October 9, his subject being "Electricity and Current Affairs". The relationship of the electrical industry to the economic position and prospects of Great Britain was the central theme of the address, which presented not only a detailed picture of the situation of the industry in question, but also set this in perspective in its world background. "For generations," said Colonel Leeson, "cotton and coal have been the staple of our oversea trade; engineering is the staple of the future." In 1951 roughly 39 per cent, or just over $£ 1,000$ million, of the value of the exports of all kinds from Britain represented engineering products, and, of this, 1189 million came from the electrical industry.

In tracing the growth of the industry during the past fifty years, Colonel Leeson pointed out that the value of the output of the electrical manufacturers, which in 1907 was $£ 14$ million, had been estimated for the year 1951 at $£ 700$ million and, in that year, nearly six hundred thousand people were employed. Although the electrical industry thus already plays a substantial part in the country's economy, it is destined to play a greater one in the future, and the further expansion of the industry must be considered 
in relation to the general pattern of the national economy. The drive to balance Britain's overseas account by increased exports requires a very large expansion in the volume of engineering exports. Dealing with the difficulties besetting the achievement of this increase in exports, Colonel Leeson said, "The shortage of coal, our only natural resource, is obviously the major cause of our present instability. Of equal significance is the fall in human effort-in its broadest sense of every form of human endeavour. Typical of the causes of this falling off in human effort are the effects of shorter normal hours of work, the longer time spent in education and training coupled with National Service, and the changing structure of the population. These together have brought about shortages in every direction, such as in food, materials, houses, fuel, power, transport and production generally. All these factors in turn have induced alternating notehing up of costs and wages without lasting benefit, unless it be to our foreign competitors; but with lower standards of life for many. The factors are so interlinked in their cumulative effects that it is difficult to know which is cause and which is effect".

There is, of course, a correlation between the activity of the manufacturing industries and the consumption of electricity by the nation, and it is here that the position compares very unfavourably with that of the United States, where the electrical power used per worker is nearly $2 \frac{1}{2}$ times that in Britain. The urgent need for the installation of more generating plant is, of course, only too evident in the load shedding which has become customary in recent years. The attainment in Britain of a yearly rate of plant installation of $2,000 \mathrm{MW}$. is imperative, and a capital investment policy covering this rate of installation is an inescapable economic necessity:

The four basic needs for economic recovery and development in Great Britain are, in Colonel Leeson's opinion, more human effort (that is, more man-hours of work); greater production of the basic commodities such as food, coal, metals, chemicals and other essential materials; more fuel and power for industry and the home; and more capital (that is, greater savings by government, industry and individuals). "We are facing," he said, "a choice and a challenge. Are we, as individuals and a nation, content to accept with complacency the relentless trend of current affairs towards lower standards of living, or alternatively, do we take up the challenge this represents, and by courage and the exertion of more strenuous individual effort on things that really matter, change the trend towards recovery and better times?"

A considerable part of the address was devoted to reviewing the growth of employment in the electrical industry in its various branches, and Colonel Leeson gave interesting data on the distribution of professional engineers as represented by membership of the Institution of Electrical Engineers in the major subdivisions of the industry. The total number of people employed in the three main branches of the industry, namely, manufacture, electricity supply and electrical contracting, was, in 1951 , nearly 846,000 . Roughly 70 per cent of this total were employed in manufacture, 22 per cent in supply, and the remaining 8 per cent in contracting. The membership of the Institution of Electrical Engineers, exclusive of students, numbers 31,000 , and an analysis of the percentage of this membership by occupation is as follows: manufacture, $29 \cdot 8$; government services, consulting engineers and others, 22.6; electricity supply, $20 \cdot 6$; communications, 10.0 ; research, education and training, 9.9; and installation and maintenance, $7 \cdot 1$. 18 per cent of the Institution's members are serving overseas.

The education and training of all classes of personnel in the industry are, in these days, matters of exceptional importance. The direct interest of the Institution of Electrical Engineers is by its charter limited to the professional engineer; but the Institution does concern itself with the improvement of facilities for technicians and craftsmen, and it co-operates with the British Electrical and Allied Manufacturers' Association and the Radio Industries Council to that end. Colonel Leeson emphasized the close partnership in which industry, technical colleges and universities are associated in this matter of the education and training of engineers, and he urged the recognition, in relation to professional engineers, of valuable features in industry-based 'sandwich' and part-time courses which are complementary to the full-time courses of universities and technical colleges.

The problem of the needed expansion of higher technological education can, in Colonel Leeson's opinion, best be tackled by the selection, on a regional basis, of a few of the existing major technical colleges for expansion and development. These should enjoy academic freedom under a self-governing representative administration and be free from any direct control by the local education authority. "The first essential to this objective is the setting up of a small body (including a few men of high academic and professional status) under the ægis of the Government with the necessary finance and authority to select and guide the chosen colleges in consultation with professional bodies, learned societies, and industry. It would be the duty of every section of the industry to provide facilities for additional and improved training matched to the higher standard of education-a duty rich in its own economic reward."

\section{PLASTICITY OF MATERIALS}

CONFERENCE on plasticity, arranged by the British Society of Rheology, was held in the University of Southampton during September 25-27.

The diverse nature of the problems encountered in flow technology, problems which still lack a fundamental treatment, was strongly evidenced in the discussions which arose on the papers presented. In spite of their diversity, however, it is remarkable how many of these problems derive from the basic problem of test instrumentation. The momentum of rheological inquiry is still sustained, in the main, by those immediately concerned with the behaviour of real commercial materials, working with instruments designed to give some rapid index from which the relevant property can be deduced. These instruments have been evolved in turn from those developed in more fundamental laboratories where the propertios of plastic materials made classical viscometry meaningless. This necessary departure in experimental design was, unfortunately, not accompanied by an equivalent development in theoretical treatment, and the situation has become gradually worse as instruments involving more complex stress-systems have been produced on grounds of general utility. The whole line of inquiry, from that of pure research on simple systems and idealized models to that of the actual behaviour of industrial products under 